\title{
ACADEMIC AND OCCUPATIONAL ASPIRATIONS OF ADOLESCENTS IN GOKOTO STATE
}

\author{
by
}

\author{
DR. A. A. SESAY \\ Faculty of Education, \\ University of Sokoto, Nigeria.
}

\begin{abstract}
This study investigated the academic and occupational aspirations of 1174 adolescents boys and girls in attendance at 15 randomly selected secondary schools in Sokoto State. The major revelation from this study was the unrealistic aspirations the students had about their future careers. The vast majority of them would like to continue their education at the tertiary level to study Medicine, Engineering, pure Science or Law. However, their best subjects were in the Arts. Some of them in fact, did not know where the courses they indicated they would like to pursue were available. Some of them indicated, for example, that they would like to go to the College of Education, Sokoto to study Medicine. That there is a need for effective and counselling services to help these youths plan their future more realistically is a great understatement.
\end{abstract}

\section{INTRODUCTION}

The period of adolescence, a transitional period between childhood and adulthood, is one characterized by adjustment problems. The adolescent is undergoing noticeable physiological and psychological changes, and has to make adjustments (social, emotional, etc.) to the world around him. For example, he wishes for acceptance by the boys and girls of his peer group as well as to relate on a more mature level than before, to the adult group. "Well over onefourth of adolescents' major problems focus on interpersonal relationships, emotions, growing maturity and their families"' (Adams 1976: 10)

In the midst of all these adjustment problems, the adolescent boy or girl is faced with the task of making career (academic and occupational) choices that will affect his/her future life. These youths can be helped in making their careerplans, if useful and meaningful research projects are carried out in the schools to identify the teachers' problems, the administrators' problems, and most importantly, the students' problems. It is only so doing that important information would be generated to help us make better plans for the provision of the kind of education that would be relevant to the students and functional to society.

It is sad to note, however, that very few of this kind of exercise has been carried out in our schools in West Africa. We seem to be operating our educational 
systems mainly by "trial and error" despite the fact that expenditures in education take a large share of our national budgets. The Federal Government allocated $7.8 \%$ of its total recurrent and capital expenditure for 1985 to Education, Science and Technology (FRN, 1985:15). In most developing countries, 25 to 30 percent of their budgets goes to education (Castle, 1975:129).

In order to justify such massive investments, the secondary schools should provide its adolescents an education of a type commensurate with their abilities, aptitudes and interests. In this way these youths can make and realize more worthwhile and realistic aspirations. It is to this end that this study has been essentially geared, and it is my hope that the suggestions offered, based primarily on the findings, will contribute in some measure, to help students make more realistic plans for their future. Such plans would make cognizance of their abilities, post-secondary opportunities, and the realities of the job market situation in the light of present and future economic conditions of the State in particular, and the Federation in general.

\section{THE SAMPLE}

The subjects for this study consisted of 1174 Form IV students randomly selected from 15 secondary schools across Sokoto State. Of this sample, 784 (66.8 percent) were boys and 390 (33.2 percent) were girls pursuing Science, Arts and Vocational and Technical education programmes. Seventy-two percent (845) of the subjects were state indigenes.

The majority, 65 percent, of the students' parents did not have education beyond the primary school level. In fact, only 15.3 percent of them had primary education, and 26.4 percent had no formal education. The largest percentage (36.4) of the parents had koranic education. See Table 1 for a breakdown of the educational background of the parents. Only 15.0 percent had post-primary education. 


\section{TABLE 1}

Level of education of parents

\begin{tabular}{lcc}
\hline Level of education & Frequency & Percent (\%) \\
\hline & & \\
No formal education & 310 & 26.4 \\
Koranic school & 427 & 36.4 \\
Primary school & 180 & 15.3 \\
Some secondary school and/or & 153 & 13.0 \\
Vocational/Trade school & 24 & 2.0 \\
Grade II certificate holder & 19 & 1.6 \\
N.C.E. holder & 21 & 1.8 \\
First degree holder & $* 40$ & 3.4 \\
Graduate degree holder & & $100 \%$ \\
\hline$\quad$ TOTAL & 1174 & \\
\hline
\end{tabular}

*mainly non-indigenes (Expatriates) working in the State.

The majority of the students as can be seen in Table 2 came from homes where the parents/guardians were either farmers, traders/businessmen or craftsmen and artisans $35.0,32.3$ and 22.6 percent respectively.

TABLE 2 .

Fathers'/Guardians' Occupations*

Occupation $\quad$ Frequency Percent (\%)

(a) Professionals, senior civil servants, graduate teachers, executives

$50 \quad 4.3 \%$

(b) Clerks, non-graduate teachers

(c) Traders and businessmen

(d) Craftsmen and artisans

(e) Farmers

(f) Others

* Adapted from E. A. Yoloye in Psychological Guidance of the School Child. Edited by M. O. A. Durojaiye, (1978), Evans Brothers Limited, Ibadan, p. 22. 
Only as little as 4.3 percent of the parents held professional positions. One wonders where the children of the top civil servants and other executives attend secondary school. Could they be in attendance out-of-state? This is an interesting question to think about.

\section{INSTRUMENT}

Data collection which was done between October 1983 and February, 1984, was by means of precoded questionnaires administered by the author and some assistants. A total of 1220 questionnaires were administered, and 46 of them were rejected because they were returned virtually blank to be of any use to the author. 1174 were thus used for the data analysis representing 96.2 percent of the original number administered. This unusually high response rate was due to the fact that the questionnaires were administered to the subjects in group sittings and collected immediately.

\section{DATA ANALYSIS}

The questionnaires were decoded. The frequencies and percentage responses were calculated and presented in tabular form. Also, a chi-square test was performed to ascertain whether there was any significant relationship between the students' occupational aspirations and their academic abilities as determined by their best three subjects.

\section{FINDING AND DISCUSSIONS}

The major findings from this study are presented under the following three broad heading: (a) Academic aspirations of students (b) Occupational aspirations of students and (c) Relatedness of students' ability to their occupational choice.

\section{(a) Academic Aspirations of Students}

The findings under this heading are divided into the following sub-headings:

(i) Students' preferences for institution of post-secondary education. 
(ii) Students' preferences for course of study at the post-secondary level.

(iii) Students' reasonş for course preference, and

(iv) Obstacles to post-secondary education.

\section{(i) Students' Preference for Institution for Post-Secondary Education :}

An item on the questionnaire required the students to choose from among a list of tertiary education institutions the one they would prefer most to attend. The response revealed that the majority of them ( 62.0 percent) indicated a preference to attend a Nigerian University. The percentage of boys preferring University education was much higher than that of girls -74.6 and 37.1 percent respectively. The two most popular choices of University were Sokoto and Ahmadu Bello, 55 percent of the students preferring the former and 45 percent the latter.

The next most popular choice of a tertiary institution was a Polytechnic for which 12.7 percent of the students indicated a preference, and this was followed by a Federal College of Technology ( 8.8 percent). Nursing school ( 7.0 percent) and a College of Education (6.0 percent). See Table 3 for details. Only a negligible percent (1.0) indicated that they were not interested in post-secondary education. In fact, when the students were asked to express their views on the importance of securing post-secondary education, an overwhelming of them (93.9 percent) indicated that it was very important for one to receive education at this level in order to be able to succeed in life in Nigerian today. 
TABLE 3

Students' Preference for Institution of Post-Secondary Education:

\begin{tabular}{|c|c|c|c|}
\hline \multirow[t]{2}{*}{ Institutions } & \multicolumn{3}{|c|}{ Percent } \\
\hline & Boys & Girls & Total \\
\hline A Nigerian University & $\begin{array}{l}74.6 \% \\
(582)\end{array}$ & $\begin{array}{l}37.1 \% \\
(146)\end{array}$ & $\begin{array}{l}62.0 \% \\
(728)\end{array}$ \\
\hline A Polytechnic & $\begin{array}{l}4.9 \\
(38)\end{array}$ & $\begin{array}{l}28.2 \\
(111)\end{array}$ & $\begin{array}{l}12.7 \\
(149)\end{array}$ \\
\hline A College of Education & $\begin{array}{l}2.7 \\
(21)\end{array}$ & $\begin{array}{l}12.4 \\
(49)\end{array}$ & $\begin{array}{l}6.0 \\
(70)\end{array}$ \\
\hline A Federal College of Technology & $\begin{array}{l}11.5 \\
(90)\end{array}$ & $\begin{array}{l}3.3 \\
(13)\end{array}$ & $\begin{array}{l}8.8 \\
(103)\end{array}$ \\
\hline Nursing School & $\begin{array}{l}2.4 \\
(19)\end{array}$ & $\begin{array}{l}16.0 \\
(63)\end{array}$ & $\begin{array}{l}7.0 \\
(82)\end{array}$ \\
\hline $\begin{array}{l}\text { School of Health Technology } \\
\text { or other Health-related School }\end{array}$ & $\begin{array}{l}1.7 \\
(13)\end{array}$ & $\begin{array}{r}.0 \\
(0)\end{array}$ & $\begin{array}{l}1.1 \\
(13)\end{array}$ \\
\hline Another Institution & $\begin{array}{l}1.5 \\
(12)\end{array}$ & $\begin{array}{l}1.0 \\
(4)\end{array}$ & $\begin{array}{l}1.4 \\
(16)\end{array}$ \\
\hline $\begin{array}{l}\text { Not interested in Post- } \\
\text { Secondary Education }\end{array}$ & $\begin{array}{l}0.6 \\
(5)\end{array}$ & $\begin{array}{l}2.0 \\
(8)\end{array}$ & $\begin{array}{l}1.0 \\
(13)\end{array}$ \\
\hline $\begin{array}{l}\text { TOTAL } \\
\mathbf{N}=\end{array}$ & $\begin{array}{l}100 \% \\
(780)\end{array}$ & $\begin{array}{l}100 \% \\
(394)\end{array}$ & $\begin{array}{l}100 \% \\
1174)\end{array}$ \\
\hline
\end{tabular}

$(\quad)=$ number of students.

It is, however interesting as well as rather disturbing to note that while 99 percent of the students expressed a desire to proceed to tertiary education institutions, only a very small percent actually goes on. This State has never at any time filled its quota of students at the University of Sokoto. This is something that deserves very serious consideration. 


\section{(ii) Students' Preference for Course of Study:}

In addition to asking the students to indicate their choices of a postsecondary institution, they were asked to indicate the kind of course they would prefer to pursue. As can be seen from Table 4a, most of them (29.9 percent) indicated a preference for science courses, biology being the most popular, followed by chemistry and physics. Mathematics was the least popular choice. The second most popular curriculum preferred was Engineering -22.3 percent indicated this choice, followed, in order of preference, by medicine and law representing 13.2 and 8.6 percent respectively. At the bottom of the Table was Teacher Training which only $\mathbb{1} .0$ percent of the students indicated as their choice. This is a serious revelation especially when one considers the acute shortage of qualified teachers of Sokoto State origin. Other areas of vital importance to the State's development are Agriculture and Nursing, but these were not among the students' top choices either -6.9 percent opted for Agriculture and 2.8 for Nursing.

\section{TABLE $4 a$}

Students' Preference for Course of Study at the Post-Secondary Level

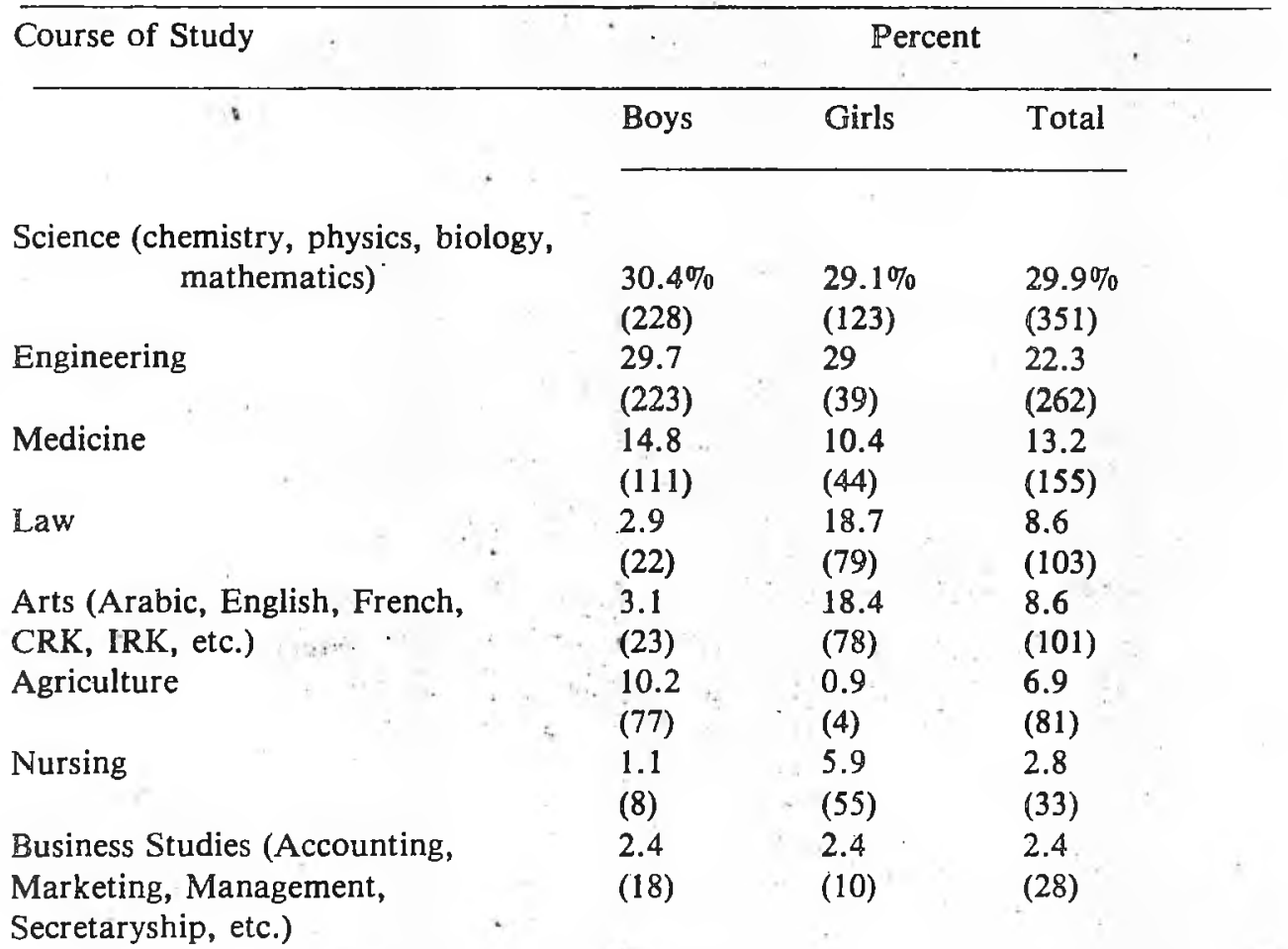


Public Administration

Political Science
Teacher Training Course
Another Course

\section{9}

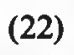

1.5

(11)

0.5

(4)

0.5

(4)
0.7

(3)

1.2

(5)

1.9

(8)

1.2

(5)
2.1

(25)

1.4

(16)

1.0

(12)

0.8

(9)

\begin{tabular}{clll}
\hline TOTAL & $100 \%$ & $100 \%$ & $100 \%$ \\
$\mathrm{~N}=$ & $(751)$ & $(423)$ & $(1174)$ \\
\hline
\end{tabular}

( ) = number of students.

Another important revelation from this study concerns the choice of Arts or Science courses. Though as many as $\mathbf{6 7 . 4}$ percent and as little as $\mathbf{2 5 . 6}$ per percent of the students were pursuing Arts and Science courses respectively as was shown earlier in Table 1 , only 8.6 percent of the entire students indicated a preference to pursue courses in Arts at the tertiary level. Interestingly, 29.9 percent indicated a preference for Science even though less than this percentage (25.6) were actually pursuing Science Programmes. It is evident that the students were making unrealistic choices - aspirations that were not commensurate with their abilities.

\section{(iii) Students' Reasons for Course Preference:}

In addition to finding out the students' course preferences, the author was interested in finding out the reason for such preferences. Table $4 \mathrm{~b}$ indicates that the most frequently oited reason (40.8 percent) for their choice of a course for post-secondary education was that Nigeria needs qualified people in the field chosen. This response was most frequently mentioned for Medicine, Engineering, Science and Nursing. Economic motivation (the prospect of making a lot of money) did not appear to be very important in influencing the students' choices. Olayinka (1973) found this to be the second most important factor that influenced career choice of youths in Lagos. Only 9.6 percents of the cases in this study reflected this reason, and this was mainly with regards to Engineering and Business fields. That people in the field chosen are highly respected in the Nigerian society was the next most frequently mentioned reason for the students' choice of a course, and this was particularly true for Law and Medicine. 
TABLE $4 b$

Students' Reasons for Course Preference

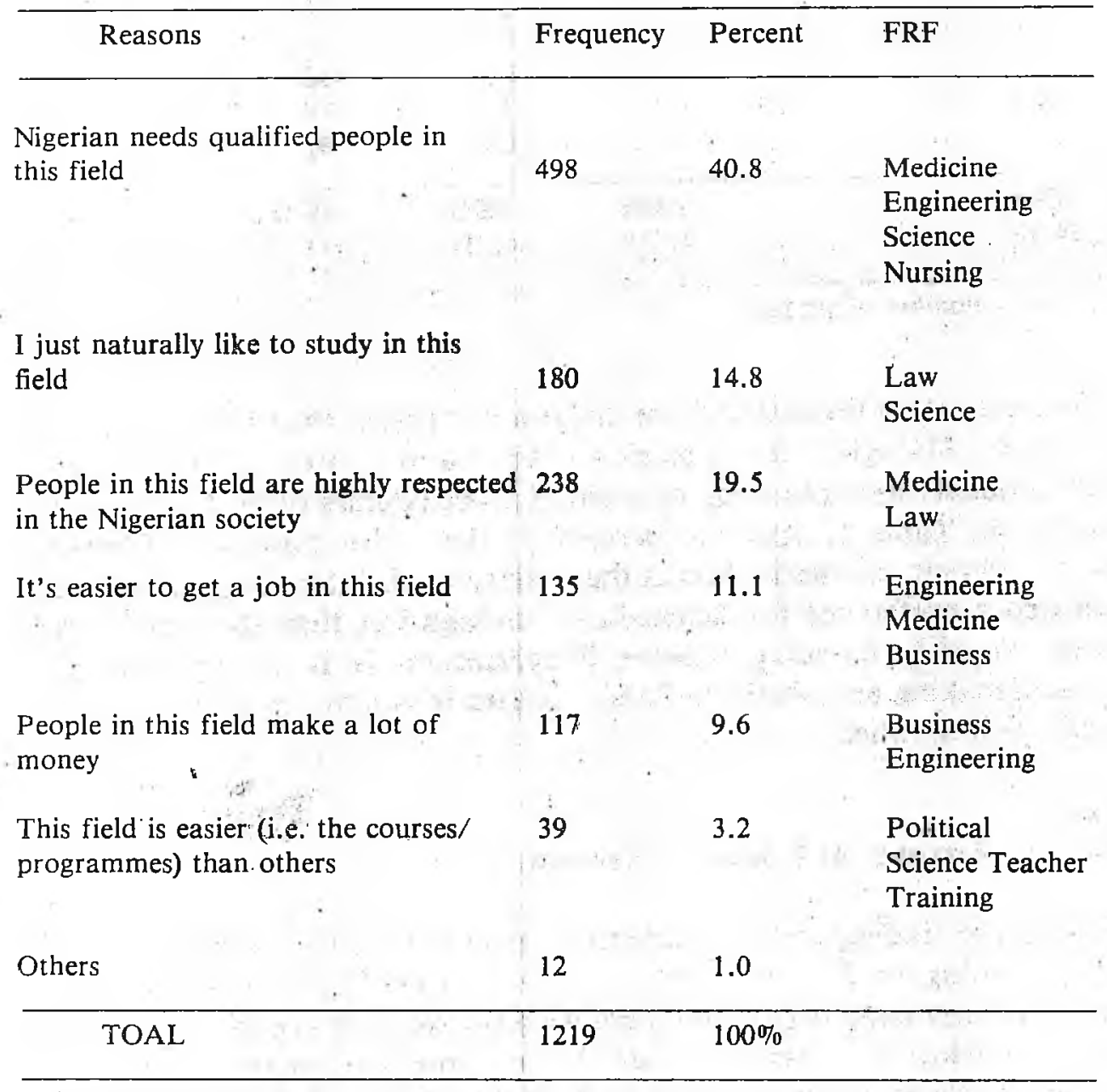

$\mathrm{N}$ is greater than actual sample size of 1174 because respondents were free to choose more than one reason.

$\mathrm{FRF}=$ Fields to which response/reasons were most frequent (i.e. at least 50 percent of those who preferred these field, cited the reason given).

\section{(iv) Students' foreseen Obstacles to Post-Secondary Education}

Although as indicated earlier, as many as 93.9 percent of the students expressed the desire to acquire post-secondary education, a very significant proportion (49.1 percent) of them indicated that they foresaw some obstacles in 
their way to realizing this desire. I asked them to indicate what those obstacles were, and the most frequently mentioned obstacle was finance. It should be remarked that most of the data for this study were collected prior to the Military take-over, and there was no indication by the then civilian regime that school fees would be introduced in the State's secondary schools. With the introduction of schools fees, the abolition of transport allowances to students and the free launch programme, and the reintroduction of poll tax soon to become a reality in the State, the pessimism these students expressed about their chances to acquire post-secondary education becomes more evident. May-Parker's study (1980) and Sesay (1981) in Sierra Leone also revealed financial problems as the major contributing factor to the secondary school drop-out problem.

\section{(b) Occupation Aspirations of Students}

Under this heading the findings are sub-divided into the following headings: (i) students' choice of occupations (ii) reasons for their occupational choices (iii) relatedness of students' academic abilities to their occupational aspirations.

\section{(i) Students' Choice of Occupations}

An item on the questionnaire sought information about the students' occupational preferences. From the results presented in Table 5a, it can be seen that most of the students ( 25.4 percent) indicated a preference for a career in Engineering with a higher percentage of the boys (30.2) than the girls (17.7 percent) indicating this preference. There was however, a slightly higher percentage of girls (27.6) than boys (19.7) preferring Medicine which was the second most popular choice. Many studies have shown that the most popular career choices are Medicine and Engineering. The studies by Fabunmi (1981), Okon (1978) and Olayinka (1973) are good examples. Teaching at the University or College level ranked much higher (12.1 percent) than the rest of the other occupations chosen by the students. I guess the students perceived University or College teaching to be more prestigious than teaching in the schools for as can be seen from the Table, even though a secondary school teacher came next in the students' order of preference, the percentage dropped sharply to about a half. Teaching in a primary school ranked last among the occupations chosen - less than 1 percent of the students cited this occupation, and in fact, not a single boy indicated a preference for this field of work. This picture is similar to the one from Yoloye's (1978) investigation in Nigeria. The selectivity indices for professions like Medicine, Engineering and Law are always much higher than those for Teaching, Agriculture and.others. People tend to go into teaching as the last resort when other venues have been explored without success. 
TABLE 5a

Students' Choices of Occupations

\begin{tabular}{|c|c|c|c|}
\hline Occupation & & Perc & \\
\hline & Male & Female & Total $\%$ \\
\hline An Engineer & $\begin{array}{l}30.2 \% \\
(218)\end{array}$ & $\begin{array}{l}17.7 \% \\
(80)\end{array}$ & $\begin{array}{l}25.4 \% \\
(298)\end{array}$ \\
\hline A Medical Doctor & $\begin{array}{l}19.7 \\
(142)\end{array}$ & $\begin{array}{l}22.6 \\
(102)\end{array}$ & $\begin{array}{l}(20.8) \\
(244)\end{array}$ \\
\hline A University/College Instructor: & $\begin{array}{l}13.2 \\
(94)\end{array}$ & $\begin{array}{l}10.6 \\
(48)\end{array}$ & $\begin{array}{l}12.1 \\
(142)\end{array}$ \\
\hline A Secondary School Teacher & $\begin{array}{l}4.8 \\
(35)\end{array}$ & $\begin{array}{l}9.1 \\
(41)\end{array}$ & $\begin{array}{l}6.5 \\
(76)\end{array}$ \\
\hline $\begin{array}{l}\text { A businessman/woman-Contractor- } \\
\text { ship for supply of materials and } \\
\text { equipment }\end{array}$ & $\begin{array}{l}5.7 \\
(41)\end{array}$ & $\begin{array}{l}7.1 \\
(32)\end{array}$ & $\begin{array}{l}6.2 \\
(73)\end{array}$ \\
\hline An Agriculturist & $\begin{array}{l}8.0 \\
(58)\end{array}$ & $\begin{array}{l}1.5 \\
(7)\end{array}$ & $\begin{array}{l}5.5 \\
(65)\end{array}$ \\
\hline A Lawyer & $\begin{array}{l}1.7 \\
(12)\end{array}$ & $\begin{array}{l}11.7 \\
(53)\end{array}$ & $\begin{array}{l}5.5 \\
(65)\end{array}$ \\
\hline $\begin{array}{l}\text { An officer in one of the armed } \\
\text { forces }\end{array}$ & $\begin{array}{l}7.4 \\
(53)\end{array}$ & $\begin{array}{l}1.8 \\
(8)\end{array}$ & $\begin{array}{l}5: 2 \\
(61)\end{array}$ \\
\hline A Nurse & $\begin{array}{l}1.2 \\
(9)\end{array}$ & $\begin{array}{l}10.6 \\
(48)\end{array}$ & $\begin{array}{l}4.9 \\
(57)\end{array}$ \\
\hline A Customs Officer & $\begin{array}{l}4.0 \\
(29)\end{array}$ & $\begin{array}{l}2.2 \\
(10)\end{array}$ & $\begin{array}{l}3.3 \\
(39)\end{array}$ \\
\hline A Health Technologist & $\begin{array}{l}2.2 \\
(16)\end{array}$ & $\begin{array}{l}2.4 \\
(11)\end{array}$ & $\begin{array}{l}2.3 \\
(27)\end{array}$ \\
\hline A Primary School Teacher & $\begin{array}{l}0.0 \\
(0)\end{array}$ & $\begin{array}{l}1.8 \\
(8)\end{array}$ & $\begin{array}{l}0.7 \\
(8)\end{array}$ \\
\hline Another Occupation & $\begin{array}{l}2.1 \\
(15)\end{array}$ & $\begin{array}{l}0.9 \\
(4)\end{array}$ & $\begin{array}{l}1.6 \\
(19)\end{array}$ \\
\hline $\begin{array}{l}\text { TOTAL } \\
\mathrm{N}=\end{array}$ & $\begin{array}{l}100 \% \\
(722)\end{array}$ & $\begin{array}{l}100 \% \\
(452)\end{array}$ & $\begin{array}{l}100 \% \\
(1174)\end{array}$ \\
\hline
\end{tabular}


Agriculture, did not seem to attract many students despite its importance to the nation's development. Only 5.5 percent indicated a preference for a career in this field with more boys ( 8.0 percent) than girls (1.5. percent) choosing this area. The Law profession did not seem to attract many students - only 5.5. percent of them indicated this area. The girls were, however, more inclined to choose Law than the boys - a marked difference of 10 percent.

\section{(ii) Students' Reasons for their Occupational Choices:}

The author was interested in finding out why the students has preferred the courses they had chosen, as well as the reasons for their preference of the occupations chosen. As is shown in Table $5 \mathrm{~b}$, the vast majority of them (39.1 percent) preferred the occupations chosen because of the nation's manpower needs. This was particularly true for Medicine and Engineering. The two next most frequently mentioned reasons were the students' intrinsic interest in the occupation and that persons in the field are accorded high respect -23.1 and 18.1 percent respectively. It is interesting to note that only in very few cases $(9.9$ percent) was economic reason (i.e. the hope to make a lot of money) given as the motivating factor for the choice of an occupation.

TABLE 5b

Reasons for Students Occupation Choice

\begin{tabular}{llll}
\hline Reasons & Frequency & Percent \% & FRF \\
\hline Nigeria needs people in this field & 473 & 39.1 & $\begin{array}{l}\text { Medicine } \\
\text { Engineering }\end{array}$ \\
It's easier to get a job in this field & 101 & 8.4 & $\begin{array}{l}\text { Teaching } \\
\text { Nursing }\end{array}$ \\
One makes a lot of money is this field & 120 & 9.9 & $\begin{array}{l}\text { Business } \\
\text { Contract and } \\
\text { Customs }\end{array}$
\end{tabular}


Persons in this field are highly respected in the Nigerian society

I just naturally like to work in this field

Other Reasons

$\begin{array}{lll}219 & 18.1 & \begin{array}{l}\text { Medicine } \\ \text { Law }\end{array} \\ 279 & 23.1 & \text { Law } \\ & \begin{array}{l}\text { Engineering } \\ \text { Science }\end{array}\end{array}$

$17 \quad 1.4$

\begin{tabular}{l} 
TOTAL $1209 \quad 100 \%$ \\
\hline $\mathrm{N}$ is greater than 1174 because the respondents were free to choose more than one \\
reason. \\
FRF $=$ Fields to which responses/reasons were most frequent
\end{tabular}

\section{(c) Relatedmess of Students' Ability to their Occupational Choices:}

In an attempt to determine how realistic the students were about their occupational aspirations, they were asked to list, in order of their ability, their three best subjects - that is, those in which they often made their best grades. These responses were then compared with their choices of occupation to find out if they possessed the necessary background to pursue those careers to which they aspired. This was done for Medicine, Engineering, and Law - fields for which specific prerequisites are very necessary, more particulalry for Medicine and Engineering. These were, in fact, the two most popular fields chosen by the students for their future careers.

From Table 6, it can be seen that for each of the three fields, the majority of the students did not possess the required background to enter such fields. The calculated chi-square was significant beyond the .05 level which indicates that there is a tendency for students to aspire to occupations for which they do not possess the necessary background. For example, there were many students aspiring to read Medicine or Engineerng but whose best three subjects were in the Arts - namely Arabic, Islamic Religious Knowledge (IRK), Islamic Studies, Home Economics, Hausa and History. There were 177 unrelated cases and only 67 related cases for Medicine. The situation was even worse for Engineering as the data revealed -228 and 70 unrelated and related cases respectively. 
TABLE 6

Relationship between students' Ability and their Occupational Choice

\begin{tabular}{|c|c|c|c|}
\hline \multirow{2}{*}{ Occupational Choice } & $\begin{array}{l}\text { Frequency of related- } \\
\text { ness or unrelatedness } \\
\text { of students' } \\
\text { background to } \\
\text { occupational choice }\end{array}$ & Total X $\mathrm{X}^{2}$ & \\
\hline & ${ }^{x}$ Related & t Related & \\
\hline Medicine & 177 & 244 & 13.49 \\
\hline Engineering & 228 & 298 & signifacant at \\
\hline Law & 30 & 65 & at $.01 \mathrm{df}-2$ \\
\hline
\end{tabular}

${ }^{x}$ Related $=$ At least two of students best three subjects were relevant to the field chosen

xxNot Related $=$ No subject or the students' third best subject relevant to field chosen .

The situation was, however, different for Law for which the number of those not having a good background in the prerequisite subjects was about the same as those having the relevant backgrond -30 and 35 respectively. Law as noted earlier, does not have as rigid entry requirements as the other two fields.

\section{CONCLUSION AND SUGGESTIONS}

This study which set out to investigate the academic and occupational aspirations of adolescents in Sokoto State came out with very important findings of important policy implications for the education of the youths in the State. The study revealed, among other things, that the students were very unrealistic about their academic and occupational aspirations. In fact, it is obvious that the students were expressing academic and occupational "fantasies" rather than aspirations. They had very little information to help them make realistic plans for their future "Students initiate goal-directed behaviour when they acquire the necessarv information about post-high school activities before making future plans", commented Loughary and Ripley (1974:91) Concerning this problem, Denga (1983) commented that "one of the serious deficiencies of the few existing career programmes in Nigeria is a lack of vocational information which would facilitate vocational decisions".

It should be remarked that these were students with only a little over a year left for them to finish secondary school. The frustrations that these ill-equipped 
youths may face when they go out into the world may have far-reaching effects on their future development. Going back to pick up prerequisites may be very difficult, if not impossible.

That there is therefore a need for vocational and academic counselling of out students is a great understatemerit.

Adolescents cannot be left on their own devices to choose academic programmes and occupations. They need help. As Yoloye (1978) correctly noted, "on the average, the Nigerian school-child can expect little intellectual support from home".. When one looks at the educational backgrounds of the students involved in this study, one can readily understand exactly what the writer is saying. This means that the school has a collossal role to play to help the youths plan their future.

\section{SUGGESTIONS}

The following suggestions are worth trying:

1. Each school should organize on a small scale a counselling service to help students with their choice of programmes and future careers. Such a service should, among other things, provide academic and vocational information to students to help them plan their future.

2. Guidance and counselling should be an integral part of all teacher training programmes, especially so, for secondary school teacher training programmes. This course should be compulsory for all teacher trainees. With some fundamental background in Guidance and Counselling acquired in their teacher training programme, the participation of these teachers and administrators at in-service courses/workshops will be much more useful and productive.

3. The tertiary education institutions and the Ministry of Education in the State should collaborate in some practical and meaningful guidance research projects that would, among other things, provide valuable information to help students plan their academic and occupational careers. Also, aptitude, interests and other relevant tests should be developed taking cognizance of the Nigerian environment.

4. Students in the Faculty of Education at the University of Sokoto, particulary State indigenes, should be provided Graduate Assistantship positions in Guidance and Counselling in the Faculty.

5. Early streaming of students into science schools need to be checked. Streaming at Form II is really not psychologically and pedagogically sound. Selection into science schools should be reviewed.

6. The State should organize an effective public enlightenment campaign programme through public lectures, the Radio, Television, Newspapers and other 
media to offer counselling services to the youths in secondary schools (and even University students) regarding their academic and vocational plans and to help schools organize small-scaled counselling programmes that would involve training teachers - counsellors, among other things. Such campaigns should also address parents to enlighten them on how they can help their children and the school help the children make good plans.

7. In addition to the above, the Ministry of Education could organize on a small scale, to start with, a mobile guidance and counselling programme wherein trained and qualified counsellors, potential employers, University and College officials, and other volunteers would visit schools and talk with students about their aspirations and give them important guidelines with which to make their plans.

If these, and other steps are taken we would be better able, to help our youths in planning their future in a much more realistic manner.

What every society would want to avoid is as Abiri (1974) puts it, to:

\footnotetext{
"....have so-called educated Feople who cannot find jobs". "There are jobs", he went further to state, "for which there are no suitably qualified people; we have people on jobs who should not, or are not themselves pleased, to be there; and there are many people who are on the job for the wrong reason". ".....it is no wonder then that so many people are not only inefficient but are also dissatisfied with themselves, their jobs, their families, their country and possibly the whole world," the writer concluded.
}

Definitely we would not want our adolescents to turn out to be such people. We would not want to turn out of our secondary schools adolescents who would be "square pegs who would not fit into round holes". We, therefore, must act now in order to help our adolescents make realistic plans for their future satisfaction while at the same time provide essential services to their society. Early intervention is invaluable.

\section{REFERENCES}

Abiri, J.O. (1977), "A sample study of Nigerian Adolescents" Academic and Occupational Aspirations" The West African Journal of Educational and Vocational Measurement, Vol. 4 No. 1.

Adams, J. F. (1976), Understanding Adolescents, Allyn and Bacon, Inc., Boston.

Castle, E. B. (1975), Principle of Education for Teachers in Africa, Oxford University Press, Nairobi.

Denga, D. I. (1983), "Career Development Among Youth: Implications for the 6:3:3:4 Curriculum, Guidance and Counselling for the 6:3:3:4 System of Education, Savanna Press Limited, Jos.

Fabunmi, Michael O. (1981) "Vocational Aspirations of Secondary School students in Sokoto Local Government Area," P.G.D.E. Dissertation, University of Jos, Jos, Nigeria.

Loughary, J. W., Ripley T. (1974) Career Sürvival Skills Focus on Effective Career Education, Charles E. Merrill Publishing Co., Columbus. 
May-Parker J. (1980), "Secondary School Dropouts - Girls", Sierra Leone Journal of Education, Vol. 1 No. 1

Okon, S. E. (1978), "Crisis in the Transition from School to work; Agenda for schools and Society", A paper presented to the Counselling Association of Nigeria Third Annual Conference"', University of Jos, August $2-4$

Olayinka, M.S. (1973), "Job Aspirations of Youth and Educational Provision in Lagos," West African Journal of Education. Vol. III, No. 1:

Sesay, A.A. (1981) "Thę Selective Entrance Examination and the Future Development of Children in Sierra Leone: A Follow-up Study," Ph.D. Dissertation, University of Illinois at Urbana-Champaigni:

Yoloye, E.A. (1978), "Socio-Economic Background and School Population: A Survey of the Blackground of Children in Three Types of School in the Western State of Nigeria" in M.O.A. Durojaiye (Ed.), Psychological Guidance of the School-Child, Evans Brothers Ltd., London. 